\title{
Phytoplankton primary production and its utilization by the pelagic community in the coastal zone of the Gulf of Gdańsk (southern Baltic)
}

\author{
Zbigniew Witek ${ }^{1, *}$, Stanisław Ochocki ${ }^{1}$, Modesta Maciejowska ${ }^{2}$, \\ Marianna Pastuszak ${ }^{1}$, Jan Nakonieczny ${ }^{1}$, Beata Podgórska ${ }^{2}$, Janina M. Kownacka ${ }^{1}$, \\ Tomasz Mackiewicz ${ }^{1}$, Magdalena Wrzesińska-Kwiecień ${ }^{1}$
}

${ }^{1}$ Sea Fisheries Institute, ul. Kołłątaja 1, 81-332 Gdynia, Poland

${ }^{2}$ Marine Biology Center, Polish Academy of Sciences, ul. Św. Wojciecha 5, 81-347 Gdynia, Poland

\begin{abstract}
In this study we estimated the amount and fate of phytoplankton primary production in the coastal zone of the Gulf of Gdansk, Poland, an area exposed to nutrient enrichment from the Vistula River and nearby municipal agglomeration. The investiggations were carned out at 2 sites durng 5 months in 1993 (February, April, May, August and October). A prolonged bloom penod occurred in the coastal zone. as compared to the open Gulf and the open sea waters. From Apral until October most values of gross primary production in the near-surface layer were in the range 100 to $500 \mathrm{mg} \mathrm{C} \mathrm{m}^{-3} \mathrm{~d}^{-1}$ Phytoplankton net exudate release constituted on average $5 \%$ of the gross primary production; total exudate release was estimated to be about 2 times higher. Bacterial production in the growth season was relatively low (the mean value lying between 5 and $9 \%$ of gross primary production); nevertheless, the microbial community (bacteria and protozoans) utilized a large proportion of primary production (from about $50 \%$ in April and May to $16 \%$ in October). Usually direct protozoan grazing on phytoplankton exceeded bacterial uptake of the phytoplankton exudates. In winter, summer and autumn community respiration exceeded depth-averaged primary production, indicating that external energy sources (sediment resuspension, allochthonous organic matter) play a substantial role in community metabolism.
\end{abstract}

KEY WORDS: Primary production Bacterial production Respiration Phytoplankton Protozoans Nutrents - Eutrophication Pelagic community Baltic Coastal zone

\section{INTRODUCTION}

Although the impact of nutrient enrichment on the functioning of the coastal pelagic ecosystems has been studied by numerous scientists (e.g. Rosenberg et al. 1986, Cederwall \& Elmgren 1990, Weisse 1991), it is not easy to draw general conclusions. Weisse (1991) concluded that though the abundance of bacteria, autotrophic picoplankton, small algae, heterotrophic nanoflagellates, ciliates, and metazoan microplankton increases with an increase in both nutrient loads and primary production, the relative significance of these different microorganisms for the carbon flux decreases

\footnotetext{
·E-mail:zwitek@mir.gdynia.pl
}

along eutrophication gradients; at the same time the roles played by the classic food chain (phytoplanktonzooplankton-fish) and the sedimentation increase Schiewer \& Jost (1991) indicated, however, that microorganisms, particularly bacteria, play a greater role in highly enriched lagoons along the German coast of the Baltic.

These problems have been poorly studied in the Gulf of Gdańsk, Poland. The Gulf is strongly influenced by the Vistula River, the second largest river discharging into the Baltic Sea. The Vistula River discharges as much as $30 \mathrm{~km}^{3}$ of water annually, carrying with it $85 \times$ $10^{3} \mathrm{t}$ of total nitrogen and $5 \times 10^{3} \mathrm{t}$ of total phosphorus (Dojlido et al. 1994). The impact of the discharges is exacerbated by the pollution load from the metropolitan complex of Gdańsk, Gdynia and Sopot, which has 
$800 \times 10^{3}$ inhabitants. There are some data that indicate a relatively high ratio of protozooplankton to metazooplankton biomass in the Gulf of Gdansk as compared with that in the open sea (Witek et al. 1993, Bralewska \& Witek 1995), indicating that unicellular organisms play a greater role under eutrophic conditions. There are, however, numerous essential aspects of the ecosystem, particularly the role of individual groups of planktonic microorganisms in the energy flow, that have not yet been studied in this region.

The aim of the present study, then, was to conduct a preliminary investigation of the function of the microbial loop in the enriched coastal region of the Gulf of Gdansk. The main objectives were to estimate the contribution of exudate release to the total primary production of phytoplankton, to estimate bacterial production, and to seasonally gauge the degree of utilization of the primary production and the bacterial production by the pelagic community.

\section{MATERIAL AND METHODS}

The investigations were carried out at 2 sampling sites, one $500 \mathrm{~m}$ offshore of Gdynia, where samples were collected from a motorboat, and the other one located near Sopot, $800 \mathrm{~m}$ offshore, where samples were gathered from the end of a pier (Fig. 1). The water depth at both sites was $7 \mathrm{~m}$. The samples were

Table 1. Dates and samplıng sites. 1: bacterioplankton grazing experiments; 2 : heterotrophic nanoflagellate growth rate experiments - no experiments

\begin{tabular}{|lll|}
\hline Date (1993) & Site & Experiment \\
\hline 16 Feb (F) & Gdynia & $1 ; 2$ \\
18 Feb (F) & Sopot & - \\
22 Feb (F) & Gdynia & - \\
24 Feb (F) & Sopot & 2 \\
6 Apr (A) & Gdynia & $1 ; 2$ \\
8 Apr (A) & Sopot & - \\
13 Apr (A) & Gdynia & - \\
15 Apr (A) & Sopot & $1 ; 2$ \\
11 May (M) & Gdynia & $1 ; 2$ \\
13 May (M) & Sopot & - \\
17 May (M) & Gdynia & - \\
19 May (M) & Sopot & $1 ; 2$ \\
17 Aug (Au) & Gdynia & $1 ; 2$ \\
19 Aug (Au) & Sopot & - \\
23 Aug (Au) & Gdynia & - \\
25 Aug (Au) & Sopot & $1 ; 2$ \\
12 Oct (O) & Gdynia & $1 ; 2$ \\
14 Oct (O) & Sopot & - \\
18 Oct (O) & Gdynia & - \\
20 Oct (O) & Sopot & $1 ; 2$ \\
\hline
\end{tabular}



Fig. 1 Location of sampling stations in the Gulf of Gdańsk (southern Baltic)

collected in 1993 during 5 sampling periods: in February, April, May, August, and October. During each period samples were gathered twice at each site, but some time-consuming experiments were done once at each site in each period (Table 1). Each time about 100 I of water was collected with a 5 I Niskin bottle from the near-surface layer ( $1 \mathrm{~m}$ depth). The water was poured into 1 plastic container, then homogenized and dispensed for individual measurements. Temperature, salinity, nutrients and chlorophyll a (chl a) determinations were also made at 3 and $6 \mathrm{~m}$ depths.

In situ water temperature was measured with a mercury thermometer. Salinity measurements were made with a Plessey Environmental Systems (model $6230 \mathrm{~N}$ ) salinometer. Chemical analyses were performed directly after sampling using the standard BMP (Baltic Monitoring Program) analytical methods recommended for the Baltic Sea (Grasshoff 1976, UNESCO 1983, Grasshoff et al. 1983). Absorbance measurements were made with a Beckman (model 26) spectrophotometer.

Total biologically degradable organic matter (TOM) was determined with the method of biochemical oxygen demand $\left[\mathrm{BOD}_{21}(\mathrm{TOM})\right]$, with a $21 \mathrm{~d}$ incubation 
time being sufficient for an almost complete exhaustion of available organic matter. Nine bottles (volume ca $100 \mathrm{ml}$ ) per sample were incubated, some used as control measurements during incubation (after 3 to $5 \mathrm{~d}$ and after 14 d) to ensure that the oxygen content did not drop to below $2 \mathrm{~cm}^{3} \mathrm{O}_{2} \mathrm{dm}^{-3}$, which could cause an inhibition of the organic matter degradation. The amount of biologically degradable dissolved organic matter $\left[\mathrm{BOD}_{21}(\mathrm{DOM})\right]$ was determined by the incubation of water samples that had been prefiltered through a $0.15 \mu \mathrm{m}$ membrane filter and inoculated with $0.1 \mathrm{~cm}^{3}$ of unfiltered water. The amount of biologically degradable particulate organic matter $\left[\mathrm{BOD}_{21}\right.$ (POM)] was calculated by subtracting the $\mathrm{BOD}_{21}$ (DOM) from the $\mathrm{BOD}_{21}$ (TOM). The incubations were performed in parallel at the in situ temperature and at $20^{\circ} \mathrm{C}$. The dissolved oxygen content was determined with the Winkler method (triplicate measurements).

Phytoplankton samples were preserved with Lugol's solution and the analyses were performed using Utermohl's method (1958), with an inverted microscope. Cell volumes were determined based on shape while the conversions into carbon biomass were made according to Baltic Marine Biologists (BMB) recommendations (Edler 1979).

For the determination of chl a concentrations, water samples were filtered onto GF/F filters; fractions $>20 \mu \mathrm{m}$ and $<20 \mu \mathrm{m}$ were separated by filtering through $20 \mu \mathrm{m}$ nylon screen. Chl a was extracted with $90 \%$ acetone and measured spectrophotometrically. For calculations the Jeffrey \& Humphrey (1975) formula was used.

Primary production measurements were made with the radioisotope method in light and dark bottles (Steemann-Nielsen 1952), using $\mathrm{NaH}^{14} \mathrm{CO}_{3}$; the sample activity was in the range 140 to $280 \mathrm{kBq}$ while the $\mathrm{pH}$ was in the range 9 to 10 . Incubations were performed in situ (in $100 \mathrm{~cm}^{3}$ glass bottles at a depth of $1 \mathrm{~m}$ over $3 \mathrm{~h}$ at midday) and in an incubator (in the same type of bottles but over a period of $2 \mathrm{~h}$ ). The incubator ensured the same ambient temperature as present in the sea and light at the level of $400 \mu \mathrm{mol}$ $\mathrm{m}^{-2} \mathrm{~s}^{-1}$ in the range 400 to $700 \mathrm{~nm}$ (Photosynthetically Active Radiation, PAR), roughly corresponding to $90 \mathrm{~W} \mathrm{~m} \mathrm{~m}^{-2}$. Two $8 \mathrm{~cm}^{3}$ subsamples were taken from each bottle directly after incubation for determination of total primary production. The remaining part of the sample was divided into 2 equal portions. One of them was subjected to a cascade filtration underpressure $(<0.02 \mathrm{MPa})$ through a nylon screen and glass fiber filters (GF/F) that separated the sample into $>20$ $\mu \mathrm{m}$ and 20-0.7 $\mu \mathrm{m}$ size fractions. The second portion, for determination of phytoplankton net exudation, was filtered through the GF/F filter only and 2 subsamples, $8 \mathrm{~cm}^{3}$ each, were taken from the filtrate. For liquid samples, inorganic carbon was eliminated by adding $0.5 \mathrm{~cm}^{3}$ of $0.1 \mathrm{~N} \mathrm{HCl}$ and leaving samples for $24 \mathrm{~h}$, while the samples on filters were placed in the fumes of concentrated $\mathrm{HCl}$ for 3 to $5 \mathrm{~min}$. The sample activity was measured with a Beckman LS 6000 IC scintillation counter, using $8 \mathrm{~cm}^{3}$ and $10 \mathrm{~cm}^{3}$ portions of a hydrophilic 'Ready Value' scintillation cocktail for the dry filters and the liquid samples, respectively; separate blanks were used. A relatively short incubation time gives primary production values close to 'gross' values (Platt et al. 1984). Following the BMB recommendations (Ertebjerg Nielsen \& Bresta 1984), a correction factor of 1.06 was introduced to multiply the production value in order to compensate for losses of organic ${ }^{14} \mathrm{C}$ due to phytoplankton respiration during incubation. The amount of inorganic carbon was measured with the Anderson \& Robinson method (1946). Global solar radiation was measured with a Kipp and Zonen pyranometer. Daily production was calculated by multiplying the value of production obtained during the entire in situ incubation time by the ratio of a full day's dose of light to the dose of light during the incubation period. Water transparency was measured with a Secchi disk. Approximate light conditions in the water column were derived from both the solar radiation measured during incubation and the extinction coefficient $k$, the latter calculated using an empirical formula for the Gulf of Gdańsk (Renk 1990): $k=2.4 / \mathrm{SD}$ (where SD is Secchi depth). An assumption was made that PAR constituted $50 \%$ of the global solar radiation. The assimilation number was calculated from the primary production measured in the incubator

Total bacterial number and biomass were determined with the epifluorescence method (Hobbie et al. 1977 ) using a Jena Lumar microscope. Bacteria (preserved with $1 \%$ formaldehyde solution) were collected on irgalan-black-dyed, $0.2 \mu \mathrm{m}$ Nuclepore filters and stained with acridine orange. The volume of the bacterial cells was measured with a Porton G 12 graticule mounted in the microscope eyepiece (HELCOM 1988). The rate of thymidine incorporation (TTI) was measured using the method described by Fuhrman \& Azam (1980), by adding a $9.1 \mathrm{nM}$ labelled ${ }^{3} \mathrm{H}$ thymidine solution of stock activity of $2.2 \mathrm{TBq} \mathrm{mmol}^{-1}$. The incubation was performed over $1 \mathrm{~h}$ (in February over $2 \mathrm{~h}$ ) at the in situ temperature. Activity measurements were made with the Beckman LS 6000 IC scintillation counter. Conversion factors of $1.1 \times 10^{6} \mathrm{cells}_{\mathrm{pmol}}^{-1}$

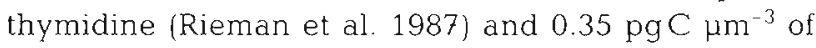
bacterial cell volume (Bjørnsen 1986) were applied for calculation of bacterial production.

Measurements of bacterioplankton grazing were carried out with a filtration-incubation method that consisted of the comparison of changes, after $24 \mathrm{~h}$ incu- 
bations, in bacterial numbers in the following fractions: $<0.8 \mu \mathrm{m}$ (only bacteria present), $<8 \mu \mathrm{m}$ (heterotrophic nanoflagellates feeding on bacteria present), and $<20 \mu \mathrm{m}$ (heterotrophic nanoflagellates and small cili. ates present). Depending on fraction, prefiltrations were made through $0.8 \mu \mathrm{m}$ or $8 \mu \mathrm{m}$ Nuclepore filters (filter diameter $47 \mathrm{~mm}$, vacuum $<0.02 \mathrm{MPa}$ ), or through a $20 \mu \mathrm{m}$ nylon screen (by gravity). After prefiltration through a $0.8 \mu \mathrm{m}$ filter the bacterial number was between 75\% (February, April) and 100\% (August) of the total number in unfiltered samples; in other fractions the differences were insignificant $(p>$ 0.05 ). Incubations were made in $70 \mathrm{~cm}^{3} i<0.8 \mu \mathrm{m}$ and $<8 \mu \mathrm{m}$ fractions) and $280 \mathrm{~cm}^{3}$ ( $<20 \mu \mathrm{m}$ fraction) polycarbonate flasks placed on a rotating wheel ( $3 \mathrm{rpm})$ in darkness at in situ temperature. Initial, as well as postincubation, bacterial numbers were measured in 3 parallel flasks, with 3 preparations analysed from each flask. The production of bacteria $(\mathrm{PB})$ in the $<0.8 \mu \mathrm{m}$ fraction was calculated according to the formulas:

$$
\begin{aligned}
\mathrm{PB} & =k_{08} B_{0} \\
\text { and } k_{08} & =\left(\ln N_{1}-\ln N_{0}\right) / t
\end{aligned}
$$

where $k_{0.8}$ denotes the rate of change in bacterial number in the fraction $<0.8 \mu \mathrm{m}_{i} N_{0}$ and $N_{1}$ are the bacterial numbers in this fraction at the beginning and at the end of incubation; $t$ is incubation time; and $B_{0}$ is the bacterial biomass in the unfiltered sample. The grazing (elimination) of bacteria (EB) in fraction $f$ was calculated according to the formula:

$$
\mathrm{EB}_{f}=\left(k_{0.8}-k_{f}\right) B_{0}
$$

where $k_{f}$ is the rate of bacterial number change in a given fraction.

Protozooplankton were analysed by various methods depending on the group. Small heterotrophic nanoflagellates ( 1.5 to $8 \mu \mathrm{m})$ were preserved with glutaraldehyde $(0.5 \%$ final concentration), stained with primuline and analysed with an epifluorescence microscope on $0.8 \mu \mathrm{m}$ black Nuclepore filters (method of Caron 1983). Ciliates, heterotrophic dinoflagellates, and other heterotrophic nanoflagellates larger than $8 \mu \mathrm{m}$ (e.g. Diaphanoeca sp., Leucocryptos spp.) were analysed similarly to phytoplankton. These analyses were preceded by the inspection of parallel samples preserved with glutaraldehyde and viewed under an epifluorescence microscope in order to identify the auto(mixo-)trophic and heterotrophic forms. Cell volumes were determined based on shape. Recalculations into carbon were made by applying the factor $0.22 \mathrm{pgC}$ $\mu \mathrm{m}^{-3}$ of cell volume for heterotrophic nanoflagellates

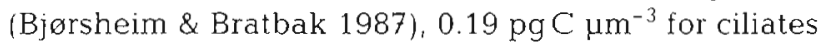
(Putt \& Stoecker 1989), and 0.13 and $0.11 \mathrm{pgC} \mathrm{m}^{-3}$ for thecate and naked dinoflagellates, respectively (Edler 1979).
The growth rate of heterotrophic nanoflagellates was determined simultaneously with measurements of bacteria grazing, by specifying the nanoflagellate number in the $<8 \mu \mathrm{m}$ fraction before and after $24 \mathrm{~h}$ incubation ( 3 replicates). Nanoflagellate production was calculated in the same way as bacterial production in the $<0.8 \mu \mathrm{m}$ fraction.

Metazooplankton were collected from 101 water samples filtered through a $40 \mu \mathrm{m}$ mesh screen, then preserved with $2 \%$ formalin solution and analysed with a stereoscopic microscope. Volume of the organisms was determined based on shape. The factors applied when recalculating the biomass into carbon were $0.064 \mathrm{~g} \mathrm{C} \mathrm{cm}^{-3}$ for crustaceans (Vinogradov \& Shushkina 1987) and $0.05 \mathrm{~g} \mathrm{C} \mathrm{cm}^{-3}$ for rotifers and the remaining forms (Parsons et al. 1977).

Total community respiration (TCR) was determined by measuring oxygen consumption during $24 \mathrm{~h}$ incubations of unfiltered seawater in 21 bottles placed in darkness at in situ temperature. The time of incubation was chosen based on the methodological experiment in which a constant oxygen drop during 6,18 , and $24 \mathrm{~h}$ incubation was found; that rate significantly dropped during the next $24 \mathrm{~h}$ incubation. Prior to each experiment, 6 bottles were filled with water, 3 of them for measurements at the beginning and 3 for measurements at the end of incubation. For oxygen measurements (Winkler method), three $100 \mathrm{~cm}^{3}$ subsamples were taken from each bottle, using a tube.

Zooplankton respiration was calculated according to the formulas:

$$
\log R=0.75 \log V-4.09
$$

for protozooplankton (Fenchel \& Finlay 1983), where $R$ is oxygen uptake $\left(\mu 1 \mathrm{O}_{2} \text { ind. }^{-1} \mathrm{~h}^{-1}\right)_{i} V$ is body volume $\left(\mu \mathrm{m}^{3}\right)$, with $Q_{10}=2.5$ adopted from Caron et al. (1990) for temperature correction; and

$$
\ln R=0.5254+0.8354 \ln C W+0.0601 T
$$

for metazooplankton (Ikeda 1985), where CW is carbon weight ( $\mathrm{mg}$ ind. ${ }^{-1}$ ); and $T$ is temperature $\left({ }^{\circ} \mathrm{C}\right.$ ).

\section{RESULTS}

\section{Environmental conditions}

The salinity in the coastal zone of the Gulf of Gdańsk ranged from 7.3 to 7.5 PSU during most of the year, typical for the near-surface layer of the southern Baltic. A drop in salinity to between 6 and 7 PSU was observed during spring as a result of the freshet outflow of the Vistula River (Fig. 2A).

Although high winter stocks of nutrients were quickly depleted by the phytoplankton spring bloom 

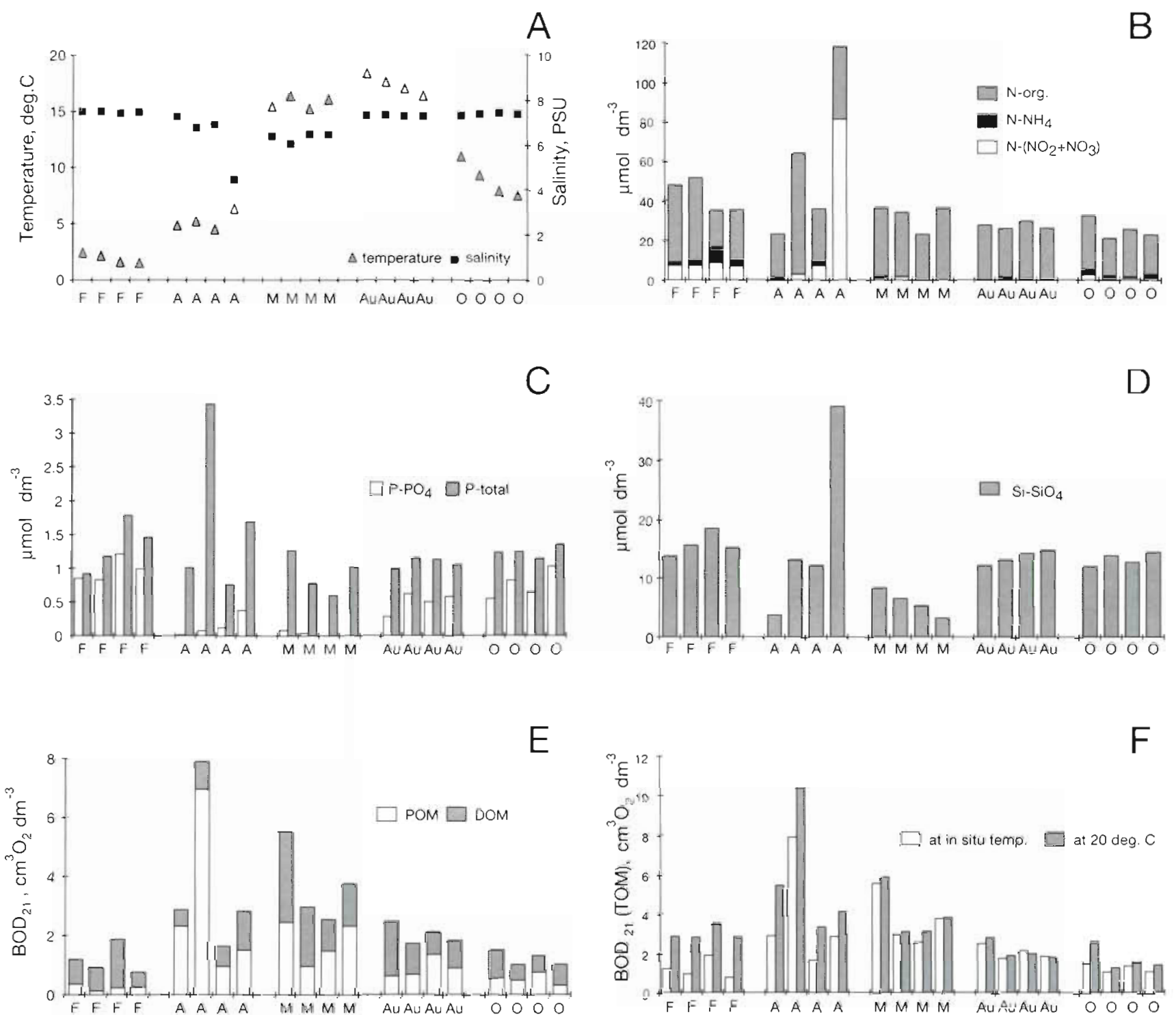

Fig. 2. Environmental parameters in the near-surface layer of the coastal zone of the Gulf of Gdansk in the seasons studied. Letters on the $x$-axes are symbols for individual sampling dates as given in Table 1. (A) Temperature and salinity of water; (B) concentrations of phosphorus compounds; (C) concentrations of nitrogen compounds; (D) silicate concentrations; (E) and (F) biochemical oxygen demand, BOD

(note the low values at the beginning of April; Figs. 2B, $C, D)$, concentrations increased again in April, due to the discharge of nutrient-rich water by the Vistula River during freshet. In particular, nitrate and silicate demonstrated an increase in concentrations, but by the middle of May these reserves, too, had been almost entirely taken up. The summer/autumn regeneration of nutrients resulted in a distinct increase in phosphate and silicate. An increase in inorganic nitrogen was weaker during this time of the year; the inorganic species were dominated by ammonia.

The greatest water transparency, exceeding $6 \mathrm{~m}$ Secchi depth, was observed in February and October, while the lowest occurred in February $(1 \mathrm{~m})$ and in April $(2 \mathrm{~m})$. The very low value observed in February resulted from very rough seas on that day.

The values of $\mathrm{BOD}_{21}$ (POM) were highest during the spring months and were correlated with phytoplankton biomass. The highest values of $\mathrm{BOD}_{21}(\mathrm{DOM})$ were observed in May. In May, August and October, the particulate and the dissolved fractions of biologically degradable organic matter occurred in similar proportions, while in February the dissolved fraction, and in April the particulate fraction, predominated (Fig. 2E). The low temperatures in February and April likely limited organic matter degradation (Fig. 2F). 
Salinity, temperature, chl a and nutrient concentrations at depths of 1, 3 and 6 m indicated that the whole water column was well mixed in all seasons except for the second half of the period of measurement in April, the first half in May, and in a few cases in August and October Intensive inflow from the Vistula River and warming of the surface layer, resulting from increased solar radiation, favoured water stratification in the April-May period.

\section{Phytoplankton and primary production}

High chl a concentrations, observed during the first sample collection in April, indicated that phytoplankton blooming must have started sometime between samplings in February and April. Phytoplankton biomass was highest in April, but high values were also observed in May (Fig. 3A, B). In these months phyto- plankton composition was dominated by dinoflagellates (mainly Peridiniella catenata and naked dinoflagellates), diatoms (Skeletonema costatum, Chaetoceros spp. and small Centrales), and the autotrophic ciliate Mesodinium rubrum. In August and October moderate biomass of diverse phytoplankton was recorded. In adition to dinoflagellates, diatoms, and $M$. rubrum, nanoflagellates and cyanobacteria contributed significantly to phytoplankton biomass.

The nanoplankton fraction $(<20 \mu \mathrm{m})$ prevailed over the entire study period (Fig. 3B). The chl a concentration in the micro- $(>20 \mu \mathrm{m})$ fraction reached about $50 \%$ of the total value only in April and once in May; in the remaining months the micro-fraction accounted for about 20 to $30 \%$, or was practically not present at all (August). Picoplanktonic algae $(<2 \mu \mathrm{m})$ played a secondary role; their biomass (microscopic observations), even at the seasonal peak in August, reached 10 to $15 \mu \mathrm{g} \mathrm{C} \mathrm{dm}{ }^{-3}$ (mainly cyanobacteria), or 5 to $20 \%$ of the
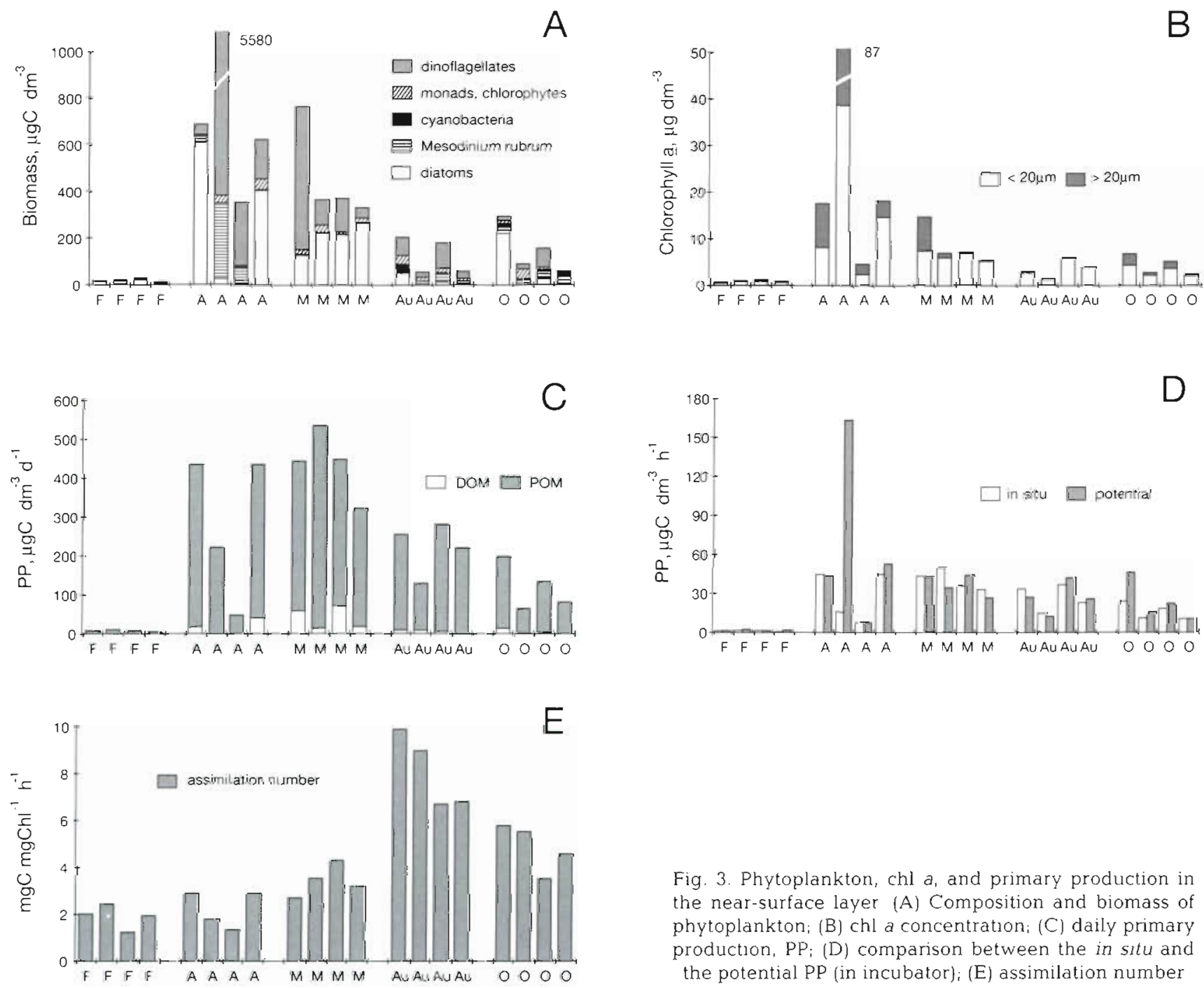

Fig. 3. Phytoplankton, chl $a$, and primary production in the near-surface layer (A) Composition and biomass of phytoplankton; (B) chl a concentration; (C) daily primary production, $\mathrm{PP}_{\mathrm{i}}$ (D) comparison between the in situ and the potential PP (in incubator); (E) assimilation number 
total phytoplankton biomass. In the remaining months picoplankton biomass did not exceed $1 \%$ of phytoplankton biomass.

In the periods when the water-column was stratified, maximum chl a concentrations were usually noted at $3 \mathrm{~m}$ depth.

Gross total primary production showed the lowest in situ values in February, not exceeding $15 \mu \mathrm{gC} \mathrm{dm}^{-3}$ $\mathrm{d}^{-1}$, while the highest values, above $400 \mu \mathrm{gC} \mathrm{dm}^{-3} \mathrm{~d}^{-1}$. were recorded in April and May (Fig 3C). With a few exceptions, the primary production measured in situ and the potential primary production measured in the incubator were comparable (Fig. 3D). PAR at $1 \mathrm{~m}$ depth was usually in the range 50 to $200 \mathrm{~W} \mathrm{~m}^{-2}$, and for these light conditions the mean difference between the potential and the in situ primary production was $5 \pm$ $22 \%$; the value of $90 \mathrm{~W} \mathrm{~m}^{-2}$ in the incubator remained within the above given range. There were 2 cases the last measurement in February and the second one in April) when PAR at $1 \mathrm{~m}$ depth was lower than $10 \mathrm{~W}$ $\mathrm{m}^{-2}$, and the production values in situ were correspondingly 3.5 and 9 times lower than those in the incubator. An approximate depth-integrated (0 to $7 \mathrm{~m}$ ) primary production was estimated on the basis of the assimilation number and the vertical chlorophyll distribution, with the assumption that at radiation exceeding $50 \mathrm{~W} \mathrm{~m}^{-2}$ the assimilation number did not depend on light, while at radiations below $50 \mathrm{~W} \mathrm{~m}^{-2}$ it linearly decreased with light. The obtained values were between 10 and $50 \mathrm{mgC} \mathrm{m} \mathrm{m}^{-2} \mathrm{~d}^{-1}$ in February, between
440 and $980 \mathrm{mgC} \mathrm{m}^{-2} \mathrm{~d}^{-1}$ in April, between 820 and $3820 \mathrm{mg} \mathrm{C} \mathrm{m}^{-2} \mathrm{~d}^{-1}$ in May, between 580 and $1860 \mathrm{mgC}$ $\mathrm{m}^{-2} \mathrm{~d}^{-1}$ in August and between 200 and $840 \mathrm{mg} \mathrm{C} \mathrm{m}^{-2}$ $\mathrm{d}^{-1}$ in October. The depth-averaged primary production constituted from 25 (in April) to over 100\% (in a few cases, chlorophyll concentrations were considerably higher at $3 \mathrm{~m}$ depth than at $1 \mathrm{~m}$ ) of primary production at $1 \mathrm{~m}$ depth; mean value was $63 \%$.

The intensity of primary production, expressed by assimilation number, was highest in August, when 7 to $10 \mu \mathrm{g} \mathrm{C} \mathrm{h}^{-1}$ were assimilated per $1 \mu \mathrm{g}$ of chl a. Similarly, high assimilation numbers were observed in October, but only on 2 dates. In the remaining seasons values ranged from 1 to $4 \mu \mathrm{gC}$ ( $\mu \mathrm{gchl} a)^{-1} \mathrm{~h}^{-1}$. The intensity of primary production in February was much the same as that observed in April (Fig. 3E).

Phytoplankton net exudate release varied from 0 to about $7 \mu \mathrm{gC} \mathrm{dm} \mathrm{dm}^{-3} \mathrm{~h}^{-1}$, with the highest values observed in April and May and the lowest in August (Table 2); there were no measurements in February. Average net exudate release constituted about $5 \%$ of total primary production

\section{Bacterioplankton and bacterial production}

The total bacterial number varied, over the entire period of the study, from 1.2 to $3.8 \times 10^{6}$ cells $\mathrm{cm}^{-3}$ and showed low interseasonal variation. Bacterial biomass was also weakly differentiated over the year, slightly

Table 2. Total primary production, phytoplankton net exudate release and bacterioplankton production (TTI method) (all in $\mu$ g C $\mathrm{dm}^{-3} \mathrm{~h}^{-1}$ ). In parentheses: percentage of total primary production

\begin{tabular}{|c|c|c|c|c|c|c|c|}
\hline \multirow{3}{*}{$\begin{array}{l}\text { Date } \\
16 \text { Feb }\end{array}$} & \multicolumn{2}{|c|}{ Total primary production } & \multicolumn{4}{|c|}{ Phytoplankton net exudate release } & \multirow{2}{*}{$\begin{array}{l}\text { Bacterial } \\
\text { production }\end{array}$} \\
\hline & In situ & Incubator & In 5 & itu & Incub & ator & \\
\hline & 0.50 & 1.16 & \multicolumn{4}{|c|}{ No measurements } & 0.09 \\
\hline 18 Feb & 2.45 & 2.52 & \multicolumn{4}{|c|}{ No measurements } & 0.06 \\
\hline $22 \mathrm{Feb}$ & 1.15 & 1.56 & \multicolumn{4}{|c|}{ No measurements } & 0.22 \\
\hline 24 Feb & 1.57 & 2.96 & & 0.11 \\
\hline 6 Apr & 54.08 & 57.28 & \multicolumn{4}{|c|}{\begin{tabular}{cccc}
\multicolumn{5}{c}{ No measurements } \\
1.86 & $(3.4)$ & 1.57 & $(2.7)$
\end{tabular}} & 0.21 \\
\hline $8 \mathrm{Apr}$ & 20.41 & 182.34 & 0 & (0) & 0.80 & $(0.4)$ & 0.23 \\
\hline $13 \mathrm{Apr}$ & 8.85 & 8.35 & 0.04 & $(0.5)$ & 0.37 & $(4.4)$ & 0.65 \\
\hline $15 \mathrm{Apr}$ & 49.55 & 58.01 & 4.60 & $(9.3)$ & 7.16 & $(12.3)$ & 0.32 \\
\hline 11 May & 59.53 & 60.08 & 6.60 & (11.1) & 7.23 & $(12.0)$ & 3.27 \\
\hline 13 May & 52.67 & 48.55 & 1.41 & $(2.7)^{\prime}$ & 2.10 & $(4.3)$ & 1.30 \\
\hline 17 May & 42.78 & 49.68 & 6.86 & $(16.0)$ & 3.50 & $(7.0)$ & 0.05 \\
\hline 19 May & 38.15 & 37.90 & 1.93 & $(5.1)$ & 1.70 & $(4.5)$ & 0.40 \\
\hline 17 Aug & 33.15 & 25.35 & 1.20 & $(3.6)$ & 1.57 & $(6.2)$ & 0.30 \\
\hline 19 Aug & 13.87 & 13.54 & 1.11 & $\{8.0\}$ & 0.69 & $(5.1)$ & 0.28 \\
\hline 23 Aug & 34.33 & 36.90 & 0.78 & $(2.3)$ & 0.88 & $(2.4)$ & 0.35 \\
\hline $25 \mathrm{Aug}$ & 23.01 & 26.62 & 0 & (0) & & $(0)$ & 0.39 \\
\hline $12 \mathrm{Oct}$ & 24.98 & 49.37 & 1.72 & $(6.9)$ & 3.55 & $(7.2)$ & 0.12 \\
\hline $14 \mathrm{Oct}$ & 13.87 & 17.98 & 0.31 & $(2.2)$ & 1.48 & $(8.2)$ & 0.14 \\
\hline $18 \mathrm{Oct}$ & 19.10 & 20.90 & 0.49 & $(2.6)$ & 0 & $(0)$ & 0.13 \\
\hline $20 \mathrm{OCl}$ & 13.36 & 15.68 & \multicolumn{4}{|c|}{ No measurements } & 0.22 \\
\hline
\end{tabular}



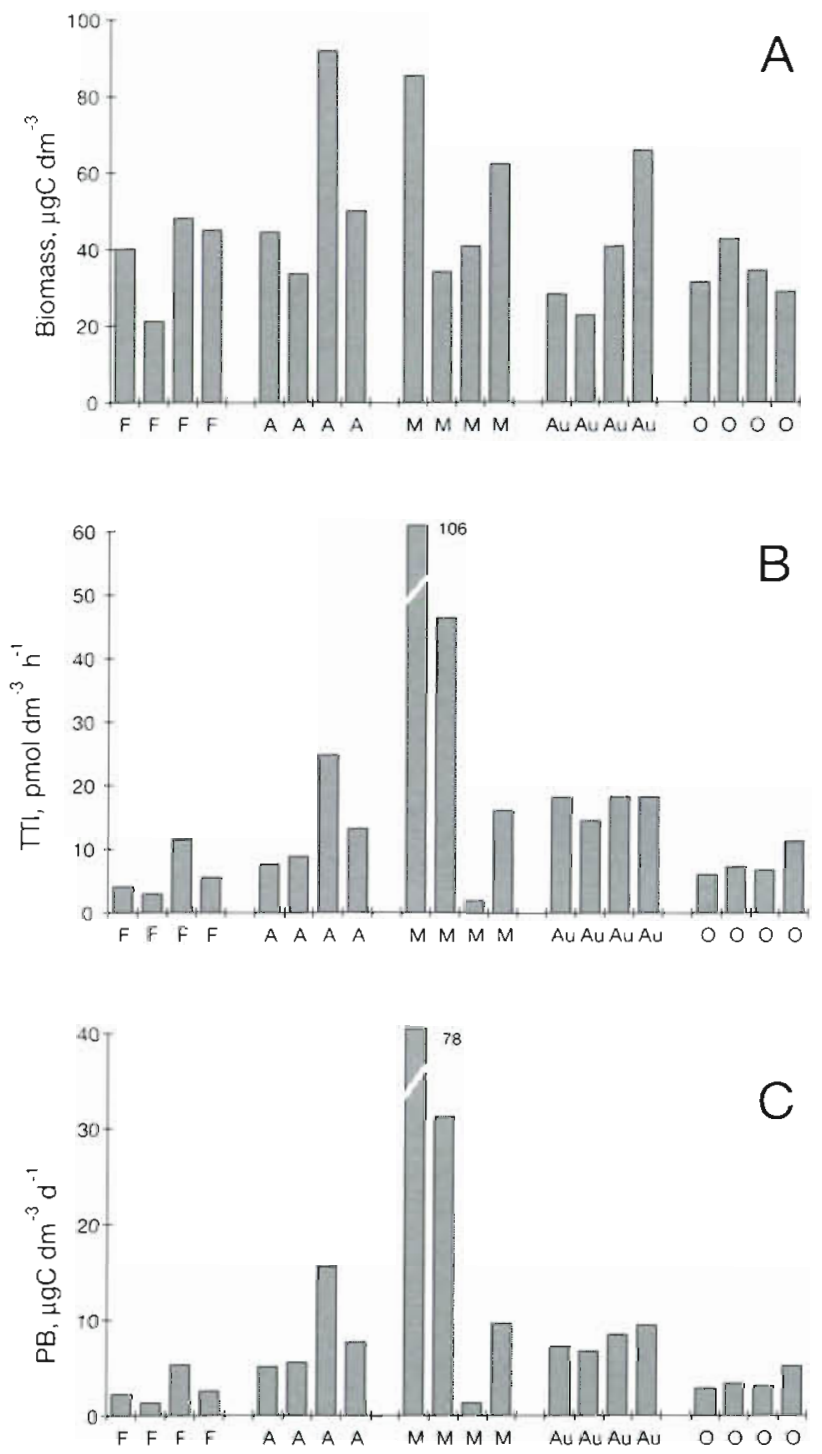

Fig. 4. Bacterioplankton in the near-surface layer. (A) Bacterial biomass; (B) rate of thymidine incorporation, TTI (C) production of bacteria, PB higher values being noted in April and May (Fig. 4A). In contrast, thymidine incorporation and bacterial production showed a distinct seasonal variability, with low values found in February and October, and maximum ones in May (Fig. 4B, C). In May, however, the minimum value of thymidine incorporation was also recorded

\section{Bacterioplankton grazing}

The changes in bacterial number, after removal of bacterivorous organisms $(<0.8 \mu$ m fraction), reflected the bacterial production. In the experiments in which the assemblage consisted of pico- and nanoplanktonic organisms $(<20 \mu \mathrm{m}$ fraction), bacterial production. was usually counterbalanced by bacteria grazing (Table 3). In most cases the rate of change of bacterial number in this fraction was low or statistically insignificant (Student's t-test, $p>0.05$ ). A considerable imbalance was observed during the first experiment in August when bacteria grazing was nearly 2 times higher than bacterial production. The removal of organisms larger than $20 \mu \mathrm{m}$ (e.g copepods Acartia tonsa, which were highly abundant then) probably resulted in intensified grazing by nanoplanktonic bacterivores.

In experiments in which the assemblage consisted of organisms smaller than $8 \mu \mathrm{m}$, the imbalance between bacterial production and grazing was greater (Table 3 ). In some cases (e.g. in August) bacteria grazing prevailed over production, indicating enhanced grazing by small bacterivores that occurs after the removal of organisms larger than $8 \mu \mathrm{m}$. In other cases (e.g. first experiment in May) bacteria grazing by organisms $<8 \mu \mathrm{m}$ was lower than bacterial production. Presumably, under natural conditions, bacteria were then grazed by the organisms larger than $8 \mu \mathrm{m}$, such as the ciliate Euplotes sp.
Table 3. Rate of change of bacterioplankton abundance $\left(k, d^{-1}\right)$ in size-fractionated cultures and the calculated production by and grazing on $(\mu \mathrm{gC}$ $\mathrm{dm}^{-3} \mathrm{~d}^{-1}$ ) bacteria. ns: not significant at $\mathrm{p}=0.05$

\begin{tabular}{|c|c|c|c|c|c|c|}
\hline \multirow[t]{2}{*}{ Date } & \multicolumn{2}{|c|}{ Fraction $<0.8 \mu \mathrm{m}$} & \multicolumn{2}{|c|}{ Fraction $<20 \mu \mathrm{m}$} & \multicolumn{2}{|c|}{ Fraction $<8 \mu \mathrm{m}$} \\
\hline & $k_{08}$ & Production & $k_{20}$ & Grazing & $k_{8}$ & Grazing \\
\hline $16 \mathrm{Feb}$ & ns & ns & ns & 0 & ns & 0 \\
\hline $6 \mathrm{Apr}$ & 0.11 & 4.9 & ns & 4.9 & ns & 4.9 \\
\hline $15 \mathrm{Apr}$ & 0.16 & 8.0 & ns & 8.0 & 0.07 & 4.5 \\
\hline $11 \mathrm{May}$ & 0.37 & 31.6 & ns & 31.6 & 0.24 & 11.5 \\
\hline 19 May & 0.24 & 15.0 & ns & 15.0 & -0.08 & 19.1 \\
\hline 17 Aug & 0.27 & 8.9 & -0.23 & 16.6 & -0.17 & 14.6 \\
\hline 25 Aug & 0.18 & 11.2 & 0.06 & 7.5 & -0.05 & 14.5 \\
\hline $12 \mathrm{Oct}$ & 0.28 & 8.8 & 0.07 & 6.6 & 0.05 & 7.2 \\
\hline $20 \mathrm{Oct}$ & 0.26 & 7.5 & -0.07 & 9.5 & -0.07 & 9.5 \\
\hline
\end{tabular}

\section{Protozooplankton}

The highest protozooplankton biomass was observed during spring (Fig. 5A-D). During that period heterotrophic dinoflagellates (Gymnodinium cf. heterostriatum) and other naked forms (as well as thecate forms from the Diplopsalis group) and non-carnivorous ciliates predominated (in April, the genera Holophryal Urotricha, Strombidium and Tintinnopsis; in May, Euplotes, Strombidium and Vorticella). The carnivorous ciliates (mainly the genera Askenasia, Didinium and 

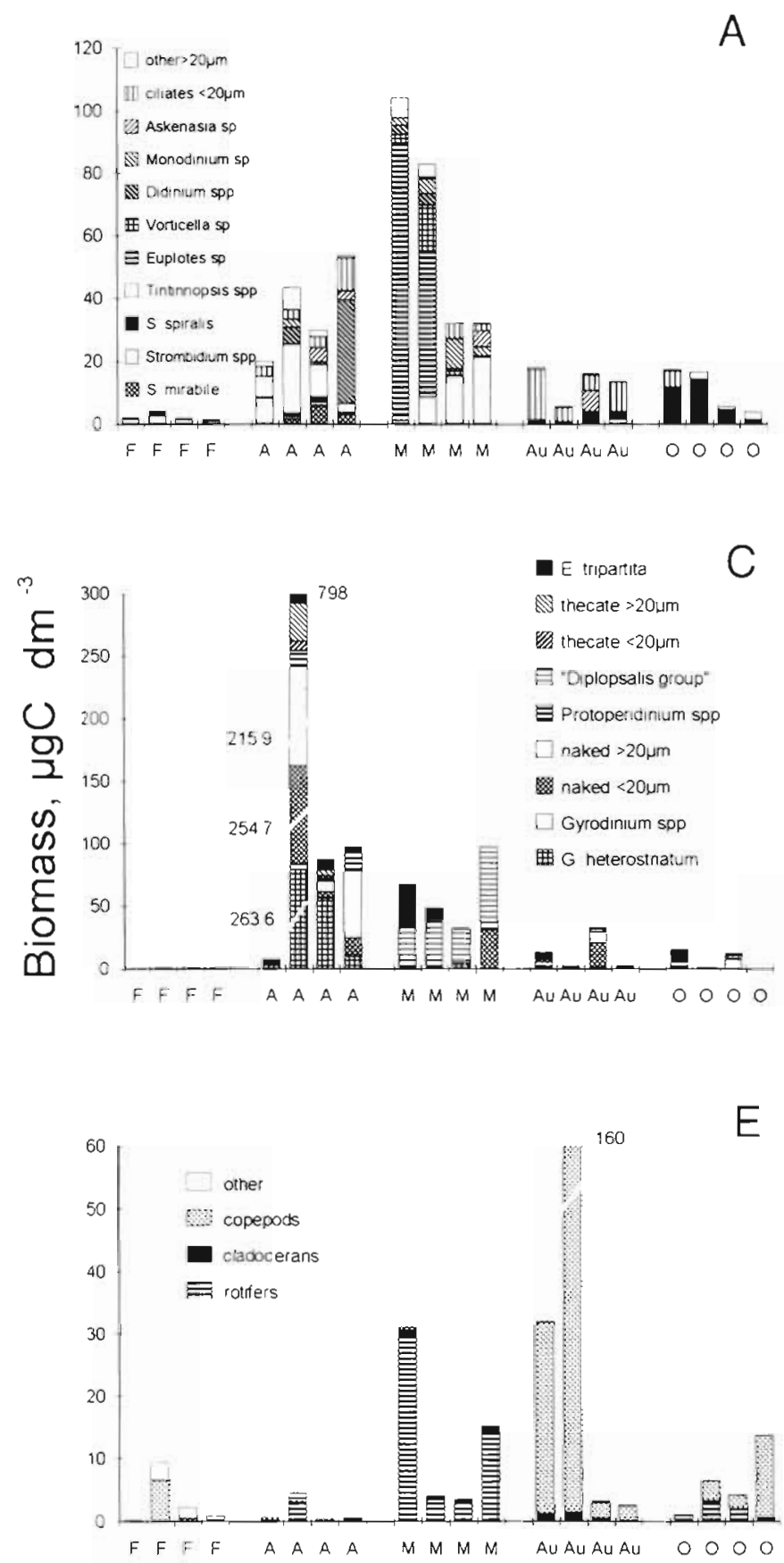

Monodinium) and Ebria tripartita also reached a peak during spring The highest biomass of heterotrophic nanoflagellates and nanoplanktonic ciliates was observed in August (Fig. 5B, D). Among the ciliates, the genus Balanion, between 7 and $15 \mu \mathrm{m}$ in size, predominated. Although small, and therefore not greatly contributing to biomass, they appeared in large numbers in different seasons and probably fed intensively upon heterotrophic nanoflagellates.
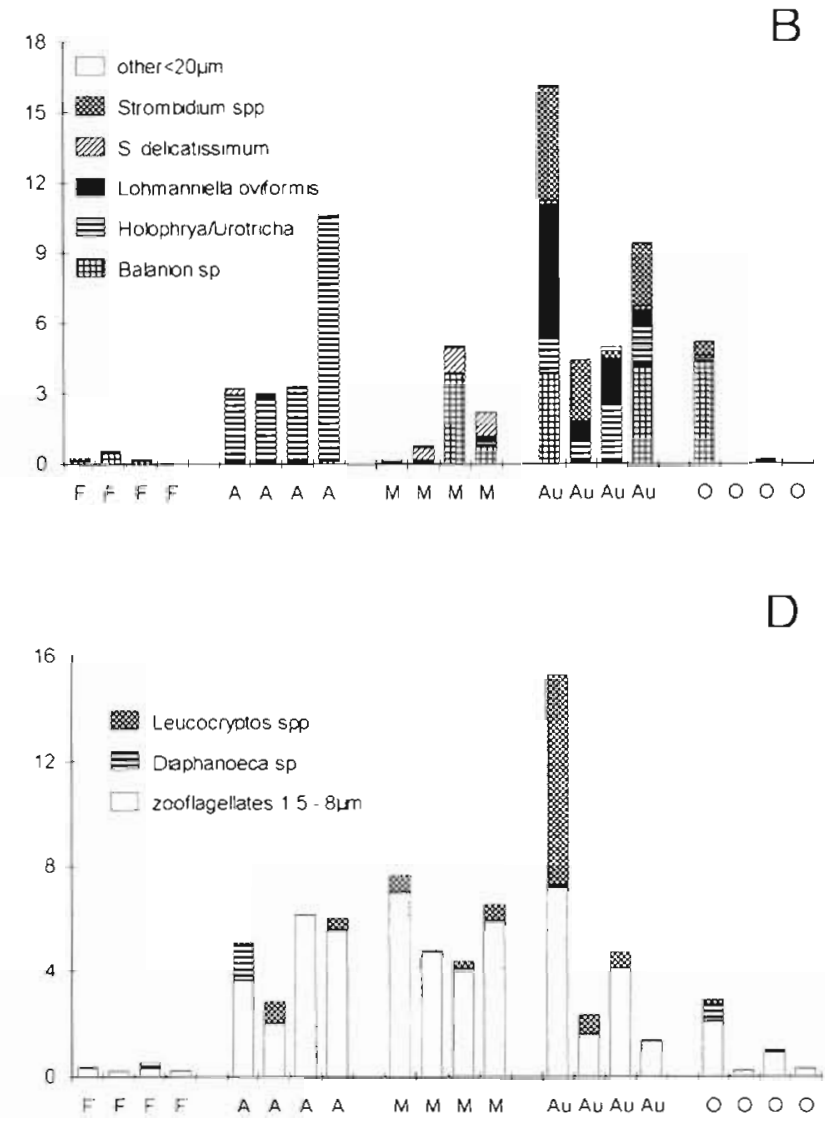

Fig. 5. Composition and biomass of zooplankton in the near-surface layer. (A) Ciliates; (B) group of small ciliates $(<20 \mu \mathrm{m}) ;(C)$ heterotrophic dinoflagellates; (D) heterotrophir nanoflagellates; (E) metazooplankton

\section{3}

$\mathrm{D}$

\section{Production of heterotrophic nanoflagellates}

Measurements of the growth rate of heterotrophic nanoflagellates were disturbed 3 times (once in May and twice in August) by the occurrence of Balanion sp. in experimental enclosures. In the remaining experimental observations the growth rate of nanoflagellates ranged from 0.35 to $0.61 \mathrm{~d}^{-1}$, with one exception in October, when, for unknown reasons, it was negative 
Table 4. Small (1.5 to $8 \mu \mathrm{m}$ ) heterotrophic nanoflagellate growth rates, production and estimated food requirements. ns: not significant at $p=0.05$; : production and food requirements uncertain

\begin{tabular}{|c|c|c|c|}
\hline Date & $\begin{array}{c}\text { Growth rate } \\
\left(d^{-1}\right)\end{array}$ & $\begin{array}{c}\text { Production } \\
\left(\mu \mathrm{gC} \mathrm{dm}-3 \mathrm{~d}^{-1}\right)\end{array}$ & $\begin{array}{l}\text { Food requirements } \\
\qquad\left(\mu \mathrm{g} C \mathrm{dm}{ }^{*} \mathrm{~d}^{-1}\right)\end{array}$ \\
\hline 16 Feb & 0.61 & 0.19 & 0.4 \\
\hline 24 Feb & 0.43 & 0.10 & 0.2 \\
\hline 6 Apr & 0.37 & 1.35 & 2.7 \\
\hline $15 \mathrm{Apr}$ & 0.58 & 3.17 & 6.3 \\
\hline 11 May & 0.35 & 2.46 & 4.9 \\
\hline 19 May & $\mathrm{ns}^{\mathrm{t}}$ & $?$ & $?$ \\
\hline 17 Aug & $0.43^{\circ}$ & $\geq 3.05$ & $\geq 6.1$ \\
\hline 25 Aug & $1.01^{d}$ & $\geq 1.32$ & $\geq 2.6$ \\
\hline $12 \mathrm{Oct}$. & -0.14 & $?$ & $?$ \\
\hline $200 \mathrm{Ot}$ & 0.57 & 0.16 & 0.3 \\
\hline
\end{tabular}

(Table 4). The highest growth rate was in August, when, despite the presence of Balanion sp., a value of $1 \mathrm{~d}^{-1}$ was recorded. Production of heterotrophic nanoflagellates showed a seasonal pattern; values recorded in April, May and August were an order of magnitude higher than those in February and October (Table 4).

\section{Metazooplankton}

The composition, as well as the biomass, of metazooplankton demonstrated great seasonal variability, with the lowest abundance in February and April and the highest in May and August (Fig. 5E). Predominance of rotifers (mainly Synchaeta baltica) and copepods (mainly Acartia tonsa and A. bifilosa) was observed in May and August. Relatively high variability in metazooplankton biomass within individual months indicates a patchy distribution of these organisms.

\section{Respiration of pelagic community}

Total community respiration was lowest in February and October and highest in May and August. The average respiration in May was about 5 times higher than the average value for February. In April high variability of total community respiration was found (Fig. 6A).

The zooplankton respiration, calculated from body mass and temperature, showed much greater seasonal variability than the total pelagic community respiration. The average zooplankton respiration was about 100 times higher in May than in February. Generally, protozooplankton respiration was considerably higher than metazooplankton respiration. In April calculated metazooplankton respiration constituted less than $1 \%$, while in the remaining months it usually made up between 2 and $10 \%$ of total zooplankton respiration. Only twice (once in August and once in October) did the respiration of metazooplankton exceed the respiration of protozooplankton (Fig. 6B)

\section{DISCUSSION}

\section{Primary production and exudate release}

Maximum concentrations of chl a occurring in the southern Baltic during the spring bloom usually remain in the range of 10 to $20 \mu \mathrm{g} \mathrm{dm}^{-3}$, although there have been some cases in which values exceeding $50 \mu \mathrm{g} \mathrm{dm}^{-3}$ were recorded (Nakonieczny et al. 1991., Renk et al. 1992, Latała 1993). Values observed during our studies in the coastal zone of the Gulf of Gdansk were within the above-mentioned average range, except for the record-high chl a concentration observed in April, which resulted from a massive bloom of the dinoflagellate Peridiniella catenata. Blooms of this species have been appearing in the Gulf of Gdańsk since the mid-80s (Bralewska 1992, Wrzołek 1993), and have not been previously reported.
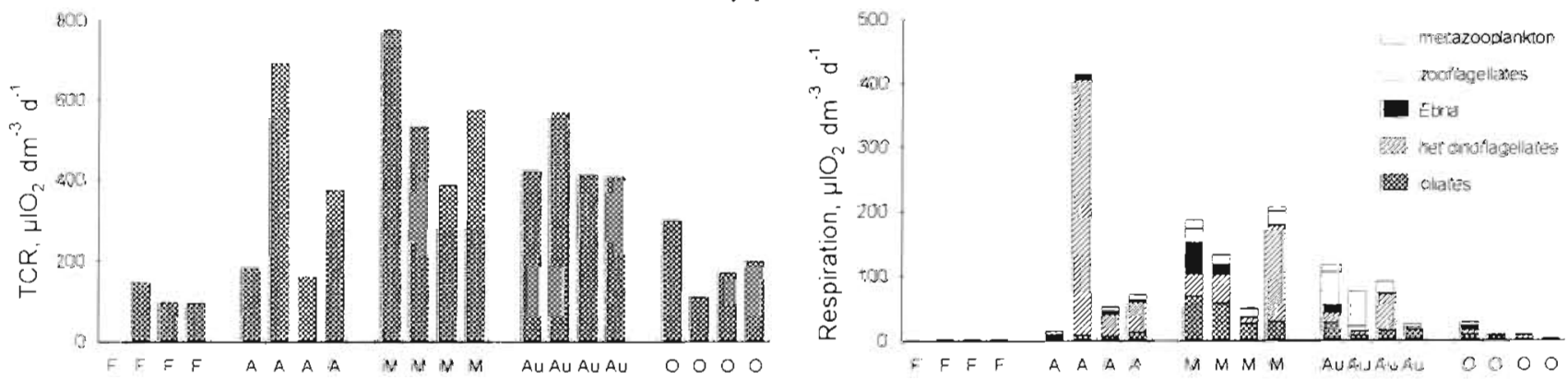

Fig. 6. Pelagic community respiration in the near-surface layer. (A) Total community respiration, TCR; (B) zooplankton respiration 

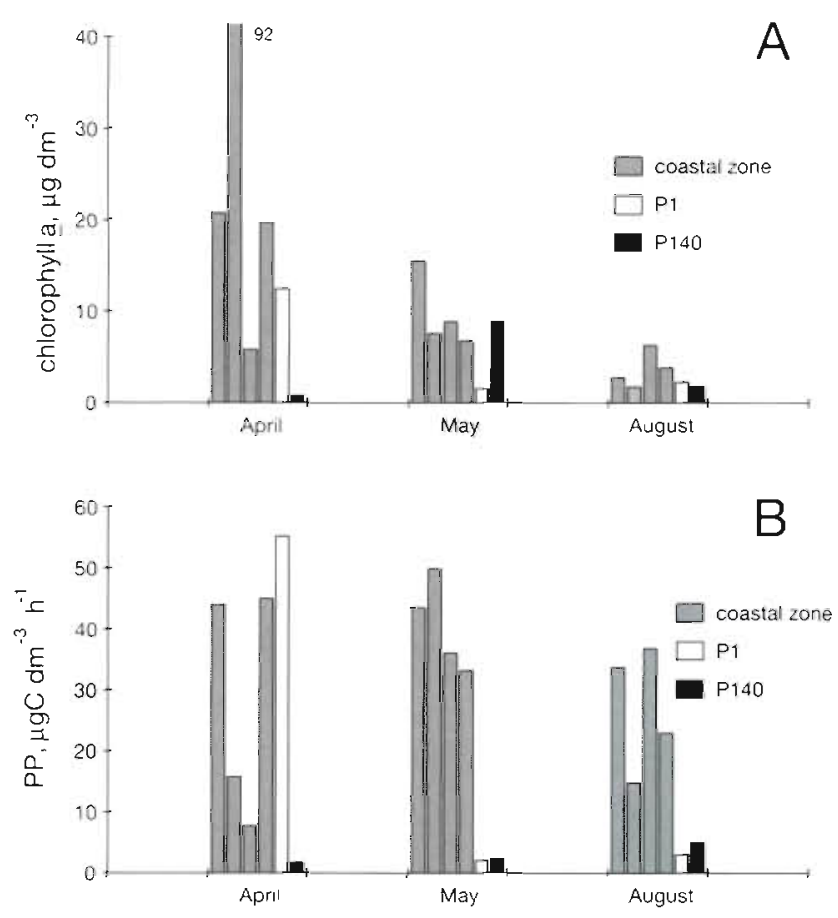

Fig. 7. (A) Chl $a$ and (B) primary production measured in 1993 in the near-surface layer of the coastal zone, open waters of the Gulf of Gdansk (Stn P1), and the open Baltic (Stn P140). Data for Stns P1 and P140 from Ochocki \& Nakonieczny (unpubl.)

As in the case of the chlorophyll concentrations, the maximum values of primary production measured during our studies did not differ from values found in the open waters of the southern Baltic (Renk et al. 1993, Ochocki et al. 1995). In the coastal zone, however, the period marked by high production and high concentrations of chl a was much longer as compared with open waters. This is illustrated by measurements made during 1993 in the coastal zone and in open waters (Fig. 7). the latter being made at Stns P1 and P140 located at a distance of 40 and $90 \mathrm{~km}$ from shore (Fig. 1).

A comparison of assimilation number (Fig 3E) with the concentration of various nitrogen forms (Fig. 2B) over the sampling periods shows that the primary production intensity was higher over the summer and autumn period when ammonia predominated ('regenerated' production). During spring, when nitrates predominated, the intensity of ('new') production was lower.

In order to estimate gross primary production, a relatively short incubation time ( 2 and $3 \mathrm{~h}$ ) was used. This short time might be considered to be too short for the stabilization of exudate release expressed as a percentage of total primary production. Wolter (1982) found that exudate release stabilized within $6 \mathrm{~h}$, and it can be seen from her Fig. 2 that after 2 and 3 h relative exudate release constituted about $70 \%$ and $80 \%$, respectively, of its final value. There are numerous authors, however, who assert that exudate release by phytoplankton is rapid (Larsson \& Hagström 1979 Mague et al. 1980, Smith et al. 1986). Larsson \& Hagström (1979) stated that during incubations the amount of dissolved organic matter labeled with ${ }^{14} \mathrm{C}$ increased during the first $2 \mathrm{~h}$, then stabilized, indicating isotopic equilibrium and a balance between production and consumption. Prolongation of incubation could even lead to underestimation of exudate release. The measurements presented in this paper did not show any significant difference between the contribution of net exudate release in total primary production obtained after a $2 \mathrm{~h}$ and after a $3 \mathrm{~h}$ incubation time (average $5.11 \pm 3.84 \%$ and $4.91 \pm 4.55 \%$ )

Values of net exudate release set the lower limit of the range of values for total piytoplankton production of dissolved organic matter, since during the incubation period some fraction of the production could have been taken up and utilized by bacteria. The upper limit of the range can be determined by summing the bacterial assimilation occurring during incubation and the net exudate release. The GIF filters collect about $50 \%$ of bacterioplankton (Lignell 1992); therefore, only a part of the ${ }^{14} \mathrm{C}$ labelled organic matter, incorporated by the bacteria, was present in the filtrate, with the other part being retained on the filter Moreover, a part of organic matter taken up by bacteria was mineralized during respiration. Middelboe et al. (1992) estimated that the ratio of bacterial production to assimilation (growth yield) in marine coastal waters lies in the range from 0.21 to 0.45 , while Daneri et al. (1994) stated that most often it variec from 0.15 to 0.45 . Using the measurements of bacterial production (Table 2) and assuming an average bacterial growth yield of 0.25 , it was possible to calculate that the bacterial assimilation during incubation corresponded to about $7 \%$ of total primary production. Keeping in mind that bacteria may utilize sources of organic matter other than phytoplankton exudate, we can estimate that total phytoplankton exudation may be about 2 times higher than the net release, and it may constitute ca $10 \%$ of gross primary production.

The exudate release constituted a rather small fraction of the total primary production in the coastal zone of the Gulf of Gdansk and was close to the lower limit of the range given by Fogg (1983), i.e. from $5 \%$ of total primary production in eutrophic waters to $40 \%$ in oligotrophic regions. Undoubtedly, the Gulf of Gdansk, particularly its coastal region, is a highly enriched environment. In other regions of the Baltic Sea, the average annual exudate release was estimated at $7 \%$ (Lignell 1990) and 12 to $16 \%$ (Larsson \& Hagström 1982) of total primary production. 


\section{Bacterial production and its utilization}

The present study enables a comparison between the estimates of bacterial production based on thymidine uptake using a constant conversion factor (Table 2) and the estimates based on observation of bacterial growth in the fraction $<0.8 \mu \mathrm{m}$ (Table 3 ). The comparison showed an almost ideal convergence of the results in April and a greater variation in the remaining part of the growing season, with a general tendency for the bacterial growth method to produce higher values. The greatest differences were observed in the first experiment in May, in which record-high thymidine incorporation showed a 2.5 -fold higher production estimate in comparison with that obtained with the growth method, and in the first experiment in October, in which the former was 3 times lower than the latter. In February, the growth method did not show statistically significant $(p>0.05)$ bacterial production, while thymidine incorporation indicated production at the level of $2 \mu \mathrm{gC} \mathrm{dm}^{-3} \mathrm{~d}^{-1}$. The mean, empirically determined conversion factor for all the experiments, except for the 3 mentioned above, was $1.36( \pm 0.25) \times 10^{6}$ cells pmol ${ }^{-1}$ thymidine, compared to $1.1 \times 10^{6}$ assumed in the thymidine method. This exercise pointed to the risk that biased results may be obtained when bacterial production in a highly variable near-shore environment is estimated solely with the thymidine method using a constant conversion factor.

Daily bacterial production measured with the thymidine method in the near-surface layer of the coastal zone of the Gulf of Gdansk in the period from April to October constituted 0.2 to $29 \%$ of gross primary production, with the most frequent values ranging from 1 to $6 \%$ (average $5 \%$ ). An exception was the month of February, when in some cases it exceeded $50 \%$ of primary production. If an empirically determined factor of $1.36 \times 10^{6}$ cells pmol $^{-1}$ thymidine were applied, then these values would be $22 \%$ higher. Assuming homogeneous vertical distribution of bacteria, bacterial production in the growth period accounted on average for $7.5 \%$ of depth-integrated primary production (applying an empiric conversion factor, for ca $9 \%$ ).

According to the review of Cole et al. (1988), average bacterial production amounts to $20 \%$ of primary production (median $16 \%$ ). Values for the Baltic Sea are slightly lower. Annual estimates made by Kuparinen (1984) were $10 \%$ of primary production; Kuosa \& Kivi (1989) reported $15 \%$, while Lignell (1990) derived $14.4 \%$ The relatively low values found in the present study could have stemmed from the fact that bacterial production was related to gross primary production. The authors cited used longer incubation times, which brought their primary production records closer to net values.
Both the highest and the lowest values of bacterial production were recorded in May. The highest values coincided with maximum phytoplankton exudate release and with the largest amounts of biologically degradable dissolved organic matter The lowest bacterial production occurred concurrently with the depletion of inorganic nitrogen and phosphorus. The important role which these elements, considered to be limiting to bacterial growth, play was emphasized for the Baltic Sea by Kuparinen \& Heinänen (1993) and Zweifel et al. (1993).

The total amount of biologically degradable organic matter determined with the $\mathrm{BOD}_{21}$ method (Fig. 2E, F) can be roughly converted from oxygen to carbon units by assuming that for every 2 atoms of utilized oxygen 1 atom of carbon is mineralized. With this conversion of $\mathrm{BOD}_{21}$ (TOM) the ratio of carbon mass in biologically degradable organic matter to nitrogen mass in total organic matter (Fig. 2B) was about 1 in February, varied between 3 and 6 in April and May, was slightly below 3 in August, and was about 2 in October. Taking into account that the $C: N$ ratio in living organic matter is about 6 and in detritus even higher (Parsons et al. 1977), it can be estimated that throughout the whole period except for spring the biologically degradable organic matter constituted less then half of total organic matter contained in water. Daily bacterial production was on average equivalent to $0.75 \%$ of the total (dissolved and particulate) amount and to $1.5 \%$ of the dissolved fraction of biologically degradable organic matter, with maximum values observed in April and May.

Phytoplankton exudation seems to be an important, but not the most important, food source for bacterioplankton. With an average bacterial growth efficiency of 0.25 and production between 5 and $9 \%$ of gross primary production, the bacteria had food requirements ranging from 20 to $36 \%$ of primary production, i.e. at least 2 times higher than phytoplankton exudation, which is estimated to be about $10 \%$ of primary production. Most likely, other sources substantially contribute to bacterial food in the region.

Bacterial production is mainly utilized by protozooplankton. The food requirement of heterotrophic nanoflagellates can be estimated (Table 4) if one assumes $50 \%$ growth efficiency for this group of protozoans (Calow 1977, Fenchel 1982, 1987, Fenchel \& Finlay 1983). Bacteria must have been the main food source of heterotrophic nanoflagellates because picoplanktonic algae are negligible in the coastal zone of the Gulf of Gdańsk. The low number of measurements of heterotrophic nanoflagellate production does not allow for far-reaching conclusions; however, the data indicate that this group could have played a major role in bacteria grazing, on several occasions being able to con- 
sume more than $3 / 4$ of bacterial production. When exceptionally high bacterial production was recorded in May (Fig 4C, first measurement), a relatively low contribution of heterotrophic nanoflagellates to bacteria grazing was observed. The ciliates Euplotes sp. and Vorticella $\mathrm{sp}$, in great abundance then, must have been the primary consumers of bacteria at that time, as has been reported in the literature (Fenchel 1969, Gast 1985, Albright et al. 1987).

\section{Zooplankton respiration}

The estimation of zooplankton respiration, based on data from the literature, incorporates several assumptions and simplifications. One of them is the assumption that Fenchel \& Finlay's (1983) formula, pertaining basically to ciliates and heterotrophic nanoflagellates, can be applied to heterotrophic dinoflagellates, for which appropriate data are missing. Studies performed by Hansen (1992), Jeong \& Latz (1994), and others indicate that the growth rate of heterotrophic dinoflagellates is lower than that of ciliates, which in turn could suggest a lower respiration rate. The same studies, however, show that heterotrophic dinoflagellates have relatively low growth efficiency. One can conclude from this that their respiration rates are not necessarily much different from those of ciliates. The application of results from laboratory measurements to calculations of zooplankton respiration under natural conditions is another simplification. In the case of protozoans this may lead to overestimation, because Fenchel \& Finlay's (1983) formula assumes actively growing individuals; in natural conditions their metabolic activity can be diversified. For metazooplankton, the application of Ikeda's (1985) formula, pertaining to non-feeding organisms with low motor activity, may lead to underestimation. Moreover, daytime sampling most likely leads to an underestimation of the metazooplankton biomass, resulting from diurnal vertical migrations and escape reactions.

Zooplankton respiration, calculated with the above limitations, contributed about $1 \%$ to the total respiration of the pelagic community in February and about $20 \%$ (on average) in the remaining period.

\section{Carbon flow in the pelagic community}

Simplified diagrams of carbon flow in the pelagic community in particular seasons are shown in Fig 8. Primary production was depth-averaged, while for the remaining parameters a homogenous distribution in the water column was assumed; measurements were averaged by month. It was assumed in calculations that total phytoplankton exudation was twice as high as the net exudate release and that it was entirely utilized by bacterioplankton. Bacterial production was calculated based on thymidine incorporation and the empirically determined conversion factor; it was assumed that in the growth period bacterioplankton production was entirely utilized by protozoans. Protozoan production and food requirements were calculated on the basis of their respiration, assuming the respiratory quotient ( $R Q$ ) of 1 , net growth efficiency for ciliates, heterotrophic nanoflagellates and Ebria tripartita of 0.5 , and for heterotrofic dinoflagellates of 0.25 ; an assimilation efficiency of 0.8 was assumed for all the organisms. It was assumed that protozoan growth was not limited by food. Grazing among protozoans was taken into account assuming that cilates from the genera Askenasia, Didinium, Monodinium, Lacrymaria and $10 \%$ of heterotrofic dinoflagellates fed on other protozoans and that the production of heterotrophic nanoflagellates and cilates from the genus Balanion was utilized by other protozoans. Protozoan production, calculated in this way, was the potential net production available for metazoans.

Unicellular organisms played the greatest role in the carbon flow in spring In April and May about $50 \%$ of gross primary production passed through the microbial community (bacteria and protozoans). This percentage gradually decreased over the growth season and in October it reached only $16 \%$. Usually, this flow was predominated by direct protozoan grazing on phytoplankton, the path through exudate release being more important in May and October. The remaining part of the primary production was utilized by metazooplankton and exported to the benthic system and/or offshore. Due to uncertain metazooplankton biomass and respiration values, the contribution of metazooplankton to utilization of primary production was not specified in Fig. 8. Earlier investigations made in the same area, however, showed that rotifers in May and June and copepods in July may reach biomass values comparable to maximum protozoan biomass (Witek 1986) and thus contribute significantly to phytoplankton grazing. At the same time both rotifers (Synchaeta spp.) and copepods (Acartia spp.) are reported as being important consumers of protozoa (Ackefors 1981, Jonsson \& Tiselius 1990, Stoecker \& McDowell Capuzzo 1990).

Despite the relatively high protozoan growth efficiency assumed, the overall efficiency of the microbial community in carbon transfer from phytoplankton to metazoans was not high and varied from 10 to $16 \%$; the reason for this was a multiple carbon transformation in a complex food web. In reality this efficiency was even lower because the microbial community was supplied not only from primary production but also from alternative food sources 

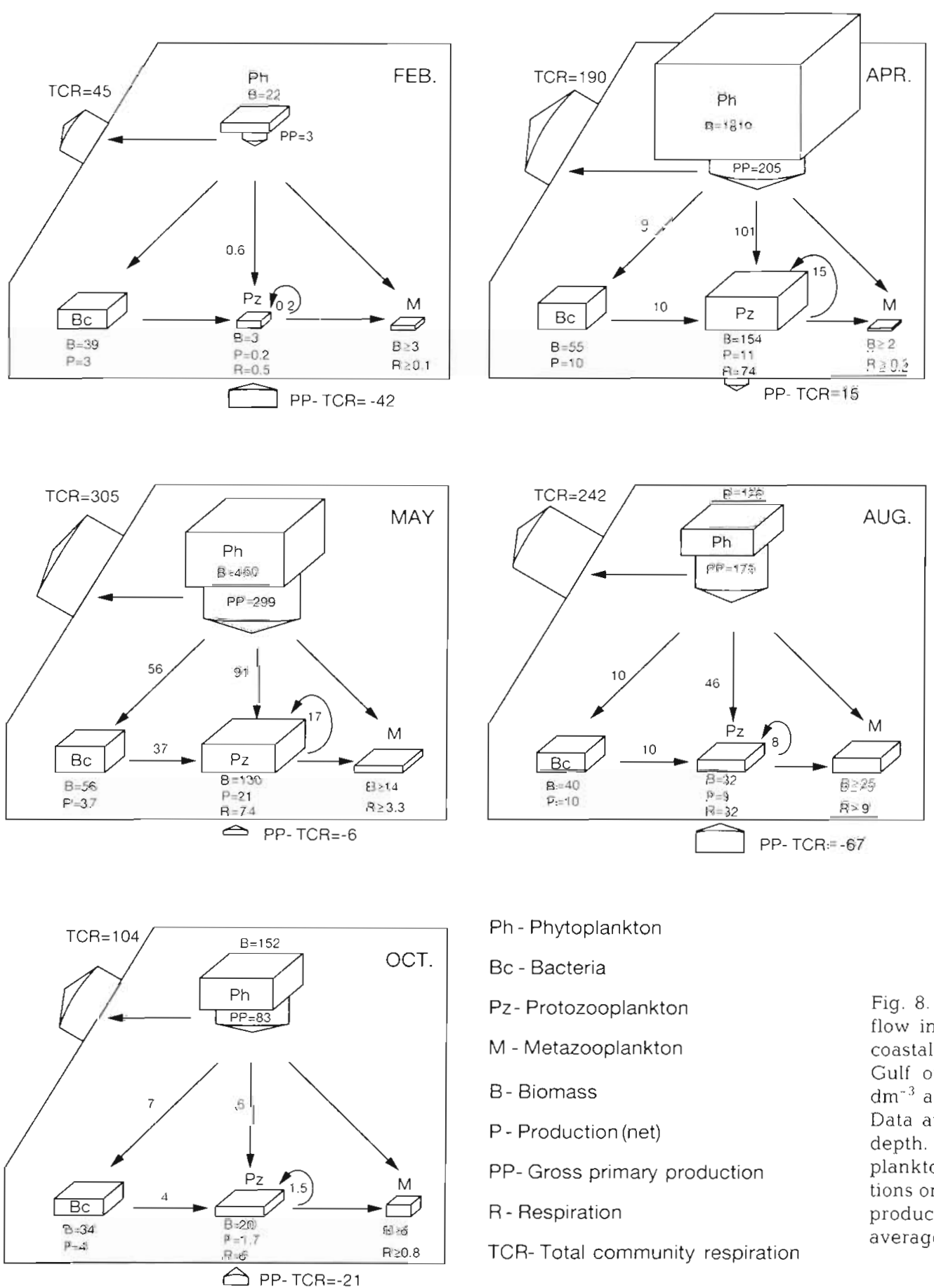

Ph-Phytoplankton

Bc - Bacteria

Pz-Protozooplankton

M - Metazooplankton

B-Biomass

P - Production (net)

PP-Gross primary production

R-Respiration

TCR-Total community respiration
Fig. 8. Main pathways of carbon flow in particular seasons in the coastal pelagic community in the Gulf of Gdańsk. Stocks in $\mu \mathrm{gC}$ $\mathrm{dm}^{-3}$ and flows in $\mu \mathrm{gC} \mathrm{dm} \mathrm{dm}^{-3} \mathrm{~d}^{-1}$ Data averaged by month and by depth. (Because of unusual phytoplankton biomass and light conditions on 8 April, potential primary production light conditions as averaged for April was used for that date)
If in a momentary carbon budget we omit both the matter exchange due to advection and the changes in biomass, then the community respiration and export to the benthic system (losses) must be compensated for with the sum of gross primary production and carbon uptake from external origins (sources). The difference between gross primary production and community respiration corresponds with a difference between export to the benthic system and carbon uptake from the external sources. In April and May uptake of allochthonous carbon and export to the benthic system were more or less balanced, while in February, August and October the former exceeded the latter. Such a situation suggests the great importance of external energy sources for the pelagic community described. The relatively low bacterioplankton production recorded appears to contradict to the above-mentioned conclusion. Phytoplankton exudate release, however, was 
insufficient to satisfy the energy requirements of the bacteria, even at their low level of production. In the shallow, coastal study area an essential source of energy could have been matter originating from resuspension of bottom sediments and allochthonous matter discharged by the Vistula River The Vistula is a great source of organic matter for the ecosystem of the Gulf of Gdansk, and annually delivers ca $500 \times 10^{3} \mathrm{t}$ of organic carbon (Niemirycz 1994), corresponding to about half of the primary production in the entire Gulf of Gdansk. The particulate fraction of this load sinks down to the bottom in the area adjacent to the river mouth; the labile fraction of the dissolved pool is probably decomposed there as well. Nevertheless, the refractory components of organic matter, whose decomposition is possible after a period of exposure to higher temperatures and/or sunlight, may be carried away and spread over a large area, thus supplying the area of study.

Approximate calculations lead to the conclusion that average bacterial growth efficiency in the coastal zone of the Gulf of Gdańsk is probably very low. Bacterial respiration could be determined by subtracting phytoplankton and zooplankton respiration from total community respiration. Approximate values of zooplankton respiration are presented in Fig. 8, but phytoplankton respiration values are missing as no information adequate for the study area was found in the literature. The available data indicate, however, that at light saturation phytoplankton respiration constitutes a few percent of primary production, and in the case of the whole euphotic layer it constitutes not more than $1 / 3$ of daily gross primary production (Keller \& Riebessel 1989, Jensen et al. 1990, Sand-Jensen et al. 1990, Latała 1991). Assuming that phytoplankton respiration constitutes $30 \%$ of gross primary production, the contribution of bacteria to community respiration varied from ca $30 \%$ in April to $70 \%$ in October, and to over $90 \%$ in February. Bacterial growth efficiency $P$ would then reach about 0.15 in April and 0.2 in May and only ca 0.05 in all remaining seasons.

Is bacterial growth based on the consumption of allochthonous organic matter much less efficient than primary-production-based growth? Daily bacterial production constituted on average only $1.5 \%$ of biologically degradable dissolved organic matter, thus suggesting high metabolic costs related to the assimilation of this energy source. Although the refractory character of allochthonous organic matter and its high $C: N$ ratio seems to explain well the relatively low bacterial production at high bacterial respiration (Hopkinson et al. 1989), it is difficult to give a precise answer to the question raised above. The difficulty arises not only from an insufficient number of respiration measurements of bacteria growing on different types of medium but also from numerous uncertainties involved in the determination of bacterial growth efficiency, as discussed by Jahnke \& Craven (1.995).

As compared with other Baltic coastal ecosystems, the coastal zone of the Gulf of Gdansk is a highly productive region. Primary production recorded in the Gulf of Gdansk in the growth season $(200$ to $3800 \mathrm{mg} \mathrm{C}$ $\mathrm{m}^{-2} \mathrm{~d}^{-1}$, monthly averages of 600 to $2100 \mathrm{mg} \mathrm{C} \mathrm{m}^{-2} \mathrm{~d}^{-1}$ ) was higher than that found in the less eutrophic waters of the Kiel Bight (seasonal averages of 400 to $800 \mathrm{mgC}$ $\mathrm{m}^{-2} \mathrm{~d}^{-1}$. Smetacek et al. 1984), in the Askö region, SE coast of Sweden (100 to $1400 \mathrm{mg} \mathrm{C} \mathrm{m}^{-2} \mathrm{~d}^{-1}$, Larsson \& Hagstrom 1982), the Tvärminne region, SW coast of Finland (seasonal averages of 100 to $1300 \mathrm{mgC} \mathrm{m}^{-2}$ $\mathrm{d}^{-1}$, Kuparinen et al. 1984), or in Pärnu Bay, Gulf of Riga, Estonia 0.5 to $5.5 \mathrm{~g} \mathrm{O}_{2} \mathrm{~m}^{-2} \mathrm{~d}^{-1}$, corresponding to 200 to $2000 \mathrm{mg} \mathrm{C} \mathrm{m}^{-2} \mathrm{~d}^{-1}$. Tenson 1995). Productivity of the Gulf of Gdańsk coastal zone was, however, not conspicious as compared with other seas. For example similar or higher values were reported from the southern Kattegat (100 to $3500 \mathrm{mg} \mathrm{C} \mathrm{m}^{-2} \mathrm{~d}^{-1}$, Richardson \& Christoffersen 1991), the Louisiana Shelf (100 to $3000 \mathrm{mg} \mathrm{C} \mathrm{m}^{-2} \mathrm{~d}^{-1}$, Redalje et al. 1994), or the Chesapeake Bay (seasonal averages, including winter averages of 1100 to $2300 \mathrm{mgC} \mathrm{m} \mathrm{m}^{-2}$. Baird \& Ulanowicz 1989), while much higher values were found in the Mississippi River Plume 400 to $8200 \mathrm{mg} \mathrm{C} \mathrm{m}^{-2} \mathrm{~d}^{-1}$. Redalje et al. 1994).

One of the peculiar features of the region studied was a high community respiration (in the growth season the majority of the results were in the range 200 to $700 \mu l \mathrm{O}_{2} \mathrm{dm}^{-3} \mathrm{~d}^{-1}$, which corresponded to 290 to $1000 \mathrm{mgO}_{2} \mathrm{~m}^{-3} \mathrm{~d}^{-1}$ ), causing the system to be netheterotrophic. Data reviews by Hopkinson (1985) and Dortsch et al. (1994) show that in coastal environments water-column respiration rates rarely exceed $500 \mathrm{mg} \mathrm{O}_{2} \mathrm{~m}^{-3} \mathrm{~d}^{-1}$, and in some regions they are even below $100 \mathrm{mgO}_{2} \mathrm{~m}^{-3} \mathrm{~d}^{-1}$; in the vicinity of river mouths, however, water-column respiration increases and values exceeding $1000 \mathrm{mgO}_{2} \mathrm{~m}^{-3} \mathrm{~d}^{-1}$ are not exceptional. In such systems, at a high rate of allochthonous matter discharge, community respiration may be higher than primary production, as found by Hopkinson (1985) in the near-shore Georgia Bight. The question arises of how such a situation may affect the functioning of particular parts of the ecosystem. Based on this study, it appears that uptake and then mineralization of the allochthonous organic matter by bacteria constitutes a 'side channel' in the carbon flow which does not have a significant impact on the structure of the remaining part of the epipelagic food web. For comparison, the contribution of the microbial loop to the carbon flow (ranging from 16 to about $50 \%$ of gross primary production) was similar to that observed in the Chesapeake Bay ecosystem, where the proportions of 
phytoplankton net production channeled through the microbial loop ranged from 25 to $50 \%$, depending on season (Baird \& Ulanowicz 1989). Serious problems resulting from high community respiration appear, however, in the deeper parts of the Gulf of Gdańsk ecosystem, in particular at the bottom of the Gdansk Deep and in the near-bottom zone below the halocline. In these subsystems, hypoxic/anoxic conditions have been observed over the past several decades, their extent depending on the one hand on material loads carried into the Gulf, and on the other on the changing meteorological/hydrological conditions in the Baltic Sea (Cyberska \& Lauer 1990, Trzosińska \& Eysiak-Pastuszak 1996).

Acknowledgements. This work was supported by a Polish Committee for Scientific Research grant, project no. 6 P205 04304. We thank 3 anonymous reviewers, Dr J. J. Govoni, NMFS, Beaufort Lab., and Prof. H. W Paerl, University of North Carolina, Chapel H.lll, for their suggestions and remarks, which made us thoroughly consider the questions raised; we are also very grateful for their linguistic corrections. Special thanks are due to P. Komorowski for help with graph preparation.

\section{LITERATURE CITED}

Ackefors H (1981) Zooplankton. In: Volpio A (ed) The Baltic Sea. Elsevier Oceanographic Serles 30. Elsevier, Amsterdam, p 238-253

Ertebjerg Nielsen G, Bresta AM (1984) Guidelines for the measurement of phytoplankton primary production. The Baltic Marine Biologists Publication 1, 2nd edn. National Agency of Environmental Proctection, Charlottenlund

Albright LJ, Sherr EB, Sherr BF, Fallon RD (1987) Grazıng of ciliated protozoa on free and particle-attached bacteria. Mar Ecol Prog Ser 38:125-129

Anderson DR, Robinson RJ (1946) Rapid electrometric determination of the alkalinity of sea water using a glass electrode. Ind Eng Chem Anal Ed 18:767-769

Baird D, Ulanowicz RE (1989) The seasonal dynamics of the Chesapeake Bay ecosystem. Ecol Monogr 59(4):329-364

Bjornsen PK (1986) Automatic determinations of bacterioplankton biomass by means of image analysis. Appl Environ Microbiol 51:1099-1104

Børsheim KY, Bratbak G (1987) Cell volume to cell carbon conversion factors for a bacterivorous Monas sp. enriched from sea water. Mar Ecol Prog Ser 36:171-175

Bralewska J (1992) Cyclic seasonal fluctuations of the phytoplankton blomass and composition in the Gdanisk Basin in 1987-1988. ICES CM/L:15

Bralewska JM, Witek Z (1995) Heterotrophic dinoflagellates in the ecosystem of the Gulf of Gdansk. Mar Ecol Prog Ser $117(1-3): 241-248$

Calow P (1977) Conversion efficiencies in heterotrophic organisms. Biol Rev Cambridge Philos Soc 52:385-409

Caron DA (1983) Technique for enumeration of heterotrophic and phototrophic nanoplankton, using epifluorescence microscopy, and comparison with other procedures. Appl Environ Microbiol 46:491-498

Caron DA, Goldman JC, Fenchel T (1990) Protozoan respiration and metabolism. In: Capriulo GM (ed) Ecology of marıne Protozoa. Oxford University Press, New York, p 307-322

Cederwall H, Elmgren R (1990) Biological effects of eutrophication in the Baltic Sea, particularly the coastal zone. Ambio 19:109-112

Cole JJ, Findlay S, Pace ML (1988) Bacterial production in fresh and saltwater ecosystems: a cross-system overview. Mar Ecol Prog Ser 43:1-10

Cyberska B, Lauer Z (1990) Oxygen and thermohaline conditions in the Polish fishing zone in 1979-1983. Oceanologia 29:3-26

Daneri G, Riemann B, Williams PJ leB (1994) In situ bacterlal production and growth yield measured by thymidine, leucine and fractionated dark oxygen uptake. J Plankton Res 16:105-113

Dojlido JR, Niemirycz E, Morawiec P (1994) Nutrient loads in the Vistula River - outflow into the Baltic Sea. Hydrological, chemical and biological processes of transformation and transport of contaminants in aquatic environments (Proc Rostov-on-Don Symp, May 1993). IAHS Publ 219:205-215

Dortch Q, Rabalais NN, Turner ER, Rowe GT (1994) Respiration rates and hypoxia on the Louisiana Shelf. Estuaries $17(4): 862-872$

Edler L (1979) Recommendation on methods of marine biological studies in the Baltic Sea. Phytoplankton and chlorophyll. The Baltic Marine Biologists Publication 5. Univ Lund

Fenchel T (1969) The ecology of marine microbenthos. IV Structure and function of the benthic ecosystem, its chemical and physical factors and the microfauna communities with special reference to the ciliated Protozoa. Ophelia 6 $1-182$

Fenchel T (1982) Ecology of heterotrophic microflagellates. If Bioenergetics and growth. Mar Ecol Prog Ser 8:225-231

Fenchel T (1987) Ecology of Protozoa. Springer-Verlag. Berlin

Fenchel T, Finlay BJ (1983) Respiration rates in heterotrophic, free-living Protozoa. Microb Ecol 9:99-122

Fogg GE (1983) The ecological significance of extracellular products of phytoplankton photosynthesis. Bot Mar 26 $3-14$

Fuhrman JA, Azam F (1980) Bacterioplankton secondary production estimates for coastal waters of British Columbia, Antarctica and California. Appl Environ Microbiol 39: $1085-1095$

Gast V (1985) Bacteria as a food source for microzooplankton in the Shlei fjord and Baltic Sea, with special references to ciliates. Mar Ecol Prog Ser 22:107-120

Grasshoff K (1976) Methods of sea water analyses. Verlag Chemie, Wernheim

Grasshoft K, Ehrhardt M, Kremling K (1983) Methods of sea water analyses. Verlag Chemie, Weinheim

Hansen PJ (1992) Prey size selection, feeding rates and growth dynamics of heterotrophic dinoflagellates with special emphasis on Gyrodinium spirale. Mar Biol 114: $327-334$

HELCOM (1988) Guidelines for the Baltic Monitoring Programme for the third stage. Part D. Biological determinants. Balt Sea Environ Proc 27 D:101-115

Hobbie JE, Daley RJ, Jasper S (1977) Use of nuclepore filters for counting bacteria by fluorescence microscopy. Appl Environ Microbiol 33:1225-1228

Hopkinson CSJr (1985) Shallow-water benthic and pelagic metabolism: evidence of heterotrophy in the nearshore Georgia Bight. Mar Biol 87:19-32

Hopkinson CS Jr, Sherr B. Wiebe WJ (1989) Size fractionated metabolism of coastal microbial plankton. Mar Ecol Prog 
Ser 51:155-166

Ikeda T (1985) Metabolic rates of epipelagic marine 200plankton as a function of body mass and temperature. Mar Biol 85:1-11

Jabnke RA, Craven DB (1995) Quantifying the role of heterotrophic bacteria in the carbon cycle: a need for respiration rate measurements. Limnol Oceanogr 40(2):436-441

Jeffrey SW. Humphrey SF (1975) New spectrophotometric equations for determining chlorophylls $a, b$, and $c$ in higher plants, algae and natural phytoplankton. Biochem Physiol Pflanzen 167:191-194

Jensen LM, Sand-Jensen K, Marcher S, Hansen M (1990) Plankton community respiration in a shallow Danish estuary. Mar Ecol Prog Ser 61:75-85

Jeong HJ, Latz MI (1994) Growth and grazing rates of the heterotrophic dinoflagellates Protoperidinium spp. on red tide dinoflagellates. Mar Ecol Prog Ser 106:173-185

Jonsson PR, Tiselius P (1990) Feeding behaviour, prey detection and capture efficiency of the copepod Acartia tonsa feeding on planktonic ciliates. Mar Ecol Prog Ser 60:35-44

Keller AA, Riebesell U (1989) Phytoplankton carbon dynamics during a winter-spring diatom bloom in an enclosed marine ecosystem: primary production, biomass and loss rates. Mar Biol 103:131-142

Kuosa H, Kivi K (1989) Bactena and heterotrophic flagellates in the pelagic carbon cycle in the northern Baltic Sea. Mar Ecol Prog Ser 53:93-100

Kuparinen $J$ (1984) Annual and seasonal fluctuation of primary productivity and overall respiration in a pelaglc plankton community off Tvärminne, SW coast of Finland. Ophelia (Suppl) 3:111-121

Kuparinen J, Heinänen A (1993) Inorganic nutruent and carbon controlled bacterioplankton growth in the Baltic Sea Estuar Coast Shelf So 37:271-285

Kuparinen J, Leppänen JM, Sarvala J, Sundberg A, Virtanen A (1984) Production and utilization of organic matter in a Baltic ecosystem off Tvärminne, southwest coast of Finland. Rapp PV Reun Cons Int Explor Mer 183:180-192

Larsson U, Hagström $\AA$ (1979) Phytoplankton exudate release as an energy source for the growth of pelagic bacteria. Mar Biol 52:199-206

Larsson U, Hagström \& (1982) Fractionated phytoplankton primary production, exudate release and bacterial production in a Baltic eutrophication gradient. Mar Biol 67: $57-70$

Latała A (1991) Photosynthesis and respiration of plants from the Gulf of Gdańsk. Acta Ichthiol Piscat 21:85-100

Latała A (1993) Chlorofil a. In: Korzeniewski K (ed) Zatoka Pucka. Instytut Oceanografii UG, Gdańsk, p 475-492

Lignell R (1990) Excretion of organic carbon by phytoplankton: its relation to algal biomass, primary productivity and bacterial secondary productivity in the Baltic Sea. Mar Ecol Prog Ser 68:85-99

Lignell R (1992) Problems in filtration fractionation of ${ }^{14} \mathrm{C}$ primary productivity samples. Limnol Oceanogr 37:172-178

Mague TH, Friberg E, Hugues DJ, Morris I (1980) Extracellular release of carbon by marine phytoplankton: a physiological approach. Limnol Oceanogr 25:262-279

Middelboe M, Nielsen B, Sondergaard M (1992) Bacterial utilisation of dissolved organic carbon (DOC) in coastal waters-determination of growth yield. In: Bjornsen PK, Riemann B (eds) Microbial ecology of pelagıc environments. Ergeb Limnol Adv Limnol 37:51-61

Nakonieczny J, Ochockı S, Renk H (1991) Long-term changes in primary production and chlorophyll concentrations in the southern Baltic. Acta Ichthyol Piscatoria 21:145-152

Niemirycz E (1994) Charakterystyka jakości wód. In: Cyber- ska B, Lauer Z, Trzosinska A (eds) Warunki srodowiskowe polskiej strefy poludniowego Bałtyku w 1993 roku. Materiały Oddziału Morskıego, Instytut Meteorologiı 1 Gospodarki Morskie\}, Gdynia, p 167-178

Ochocki S, Nakoneczny J, Chmielowski Hi, Zalewski M (1995) The hydrochemical and biological impact of the river Vistula on the pelagic system of the Gulf of Gdansk in 1994. Part 2. Primary production and chlorophyll $a$. Oceanologia 37(2):207-226

Parsons TR, Takahashi M. Hargrave B (1977) Biologoical oceanographic processes, 2nd edn. Bedford Institute. Dartmouth

Platt T, Lewis M, Geider R (1984) Thermodynamucs of the pelagic ecosystem: elementary closure conditions for biological production in the open ocean. In: Fasham MJR (ed) Flows of energy and materials in marine ecosystems. Plenum Press, New York, p 49-84

Putt M. Stoecker DK (1989) An expermentally determuned carbon:volume ratio for marine 'oligotrichous' ciliates from estuarine and coastal waters. Limnol Oceanogr 34: $1097-1103$

Redalje DG, Lohrenz SE, Fahnenstiel GL (1994) The relationship between pnmary production and the vertical export of particulate organic matter in a river-impacted coastal ecosystem. Estuaries 17(4):829-838

Renk H (1990) Produkcja pierwotna. In: Majewski A (ed) Zatoka Gdańska. Wydawnictwa Geologiczne, Warszawa, p $329-360$

Renk H, Ochocki S, Bralewska J, Nakonieczny J (1993) Produkcja pierwotna jako parametr monitorıngu Bałtyku. In Ciszewska I (ed) Międzynarodowy monitoring biologiczny Morza Bałtycklego. Instytut Ochrony Środowiska, Warszawa, p $11-22$

Renk H, Ochockı S. Nakoneczny J, Gromisz S (1992) Produkcja pierwotna południowego Battyku w latach 1981-1985 na tle średnıej wieloletniej. Stud Mater Morsk Inst Ryb w Gdyn 30A:5-28

Richardson K, Christoffersen (1991) Seasonal distribution and production of phytoplankton in the southern Kattegat. Mar Ecol Prog Ser 78:217-227

Riemann B, Bjørnsen PK, Newell S, Fallon R (1987) Catculation of cell production of coastal bacteria based on measured incorporation of ${ }^{3} \mathrm{H}$-thymidine. Limnol Oceanogr 32 : $471-476$

Rosenberg R, Larsson U, Edler L (1986) Eutrophication in marine waters surrounding Sweden. National Swedish Environmental Protection Board Report No. 3054, Solna

Sand-Jensen K, Jensen LM, Marcher S, Hansen M (1990) Pelagic metabolısm in eutrophic coastal waters during a late summer period. Mar Ecol Prog Ser 65:63-72

Schiewer U. Jost G (1991) The microbial lood web in eutrophic shallow estuaries of the Baltic Sea. Int Rev Ges Hydrobiol 76:339-350

Smetacek V, von Bodungen B, Knoppers B, Penert R, Pollehne F. Stegmann P. Zeitzschel B (1984) Seasonal stages characterizing the annual cycle of an inshore pelagic system. Rapp PV Reun Cons Int Explor Mer 183:126-135

Smith REH, Harrison WG, Irwin B, Platt T (1986) Metabolism and carbon exchange in microplankton of the Grand Banks (Newfoundland). Mar Ecol Prog Ser 34:171-183

Steemann-Nielsen E (1952) The use of radio-carbon ${ }^{14} \mathrm{C}$ for measuring organic productıon in the sea. J Cons Int Explor Mer 18:117-140

Stoecker DK, McDowell Capuzzo J (1990) Predation on Protozoa: its importance to zooplankton. J Plankton Res 12 : $891-908$ 
Tenson J (1995) Phytoplankton of the Pärnu Bay. In: Olaveer $E$ (ed) Ecosystem of the Gulf of Riga between 1920 and 1990. Estonian Academy Publishers, Tallinn, p 105-126

Trzosinska A, Łysiak-Pastuszak E (1996) Oxygen and nutrients in the southern Baltic Sea. Oceanol Stud 25(1-2): $41-76$

UNESCO (1983) Chemical methods for use in marine environmental monitoring. Manual and guides. Intergovernmental Oceanographic Commission, 12:1-53

Ütermoh. H. (1958) Zur Vervollkommung der quantitativen Phytoplankton Methodik. Mitt Int Verein Theor Angew Limnol 9:1-38

Vinogradov ME, Shushkına EA (1987) Funktsyonirovaniye planktonnykh soobshchestv epipelagiali okeana. Nauka, Moskwa

Weisse $T$ (1991) The microbial food web and its sensitivity to eutrophication and contaminant enrichment: a cross-system overview. Int Rev Ges Hydrobiol 76:327-337

Witek Z (1986) Seasonal changes in the composition and size

This article was submitted to the editor structure of plankton in the near-shore zone at the Gulf of Gdańsk. Ophelia (Suppl) 4:287-298

Witek Z, Bralewska J, Chmielowski H, Drgas A, Gostkowska J, Kopacz M, Knurowski J, Krajewska-Sołty's A, Lorenz Z, Maciejewska K, Mackıewicz T, Nakonieczny J, Ochocki S, Warzocha J, Piechura J, Renk H, Stopinskı M, Witek B (1993) Structure and function of marine ecosystem in the Gdansk Basin on the basis of studies performed in 1987 Stud Mater Oceanol 63:1-124

Wolter K (1982) Bacterial incorporation of organic substances released by natural phytoplankton populations. Mar Ecol Prog Ser 7:287-295

Wrzołek L (1993) Fitoplankton południowego Bałtyku w 1991 roku. In: Ciszewska I (ed) Międzynarodowy monitoring biologiczny Morza Bałtyckiego. Instytut Ochrony Środowiska, Warszawa, p 23-32

Zweifel UL, Norrman B, Hagström $\AA$ (1993) Consumption of dissolved organic carbon by marine bacteria and demand for inorganic nutrents. Mar Ecol Prog Ser 101:23-32

Manuscript first received: November 1, 1995

Revised version accepted: December 11, 1996 